\title{
Influence of heterozygosity and competition on morphological tree characteristics of Quercus rubra L.: a new single-tree based approach
}

\author{
Katharina Burkardt ${ }^{1}$ (D) . Tim Pettenkofer ${ }^{2}$. Christian Ammer ${ }^{1}$. Oliver Gailing ${ }^{2}$. \\ Ludger Leinemann ${ }^{2} \cdot$ Dominik Seidel $^{1} \cdot$ Torsten Vor $^{1}$
}

Received: 9 July 2020 / Accepted: 13 October 2020 / Published online: 3 November 2020

(c) The Author(s) 2020, corrected publication 2021

\begin{abstract}
In Europe, the non-native Northern red oak (Quercus rubra L.) is widely recommended for future cultivation. However, outside its natural range, Northern red oak has to date been insufficiently studied both in terms of silviculture and genetics. To clarify this, we studied the architecture of 92 (pre-) dominant Northern red oak trees in five German federal states using the non-destructive terrestrial laser scanning method (TLS). In addition, individualbased heterozygosity was calculated based on microsatellite data obtained by analyzing twelve potentially adaptive genic (EST derived markers) and eight putatively selectively neutral nuclear microsatellite markers. With these data the individual heterozygosity of the sample trees was calculated. Mean or median branch angles as well as branch angle ranges of first order branches decreased with individual heterozygosity calculated group-wise for all markers $\left(\mathrm{H}_{\mathrm{o}} \mathrm{All}\right)$ and for EST-derived markers $\left(\mathrm{H}_{\mathrm{o}} \mathrm{EST}\right)$. Most other tree characteristics, including the number of bark anomalies and mean stem non-circularity and crown characteristics such as crown volume, crown surface area, or mean branch length of first order branches responded exclusively to competition. We conclude that competition, not genetics, is the main driver of Northern red oak stem and crown characteristics. Thus, stem quality and crown dimension can primarily be controlled by silvicultural interventions. The significant relationship between Northern red oak branch angle traits and individual tree heterozygosity was unexpected, and at this time we do not have any validated explanation for this. This issue needs to be further investigated.
\end{abstract}

Keywords Northern red oak · Individual-based heterozygosity $\cdot$ Competition $\cdot$ Branch angle measures $\cdot$ Stem quality

Electronic supplementary material The online version of this article (https://doi.org/10.1007/s1105 6-020-09814-1) contains supplementary material, which is available to authorized users.

Katharina Burkardt

katharina.burkardt@uni-goettingen.de

1 Department of Silviculture and Forest Ecology of the Temperate Zones, Faculty of Forest Sciences and Forest Ecology, University of Göttingen, Büsgenweg 1, 37077 Göttingen, Germany

2 Department of Forest Genetics and Forest Tree Breeding, Faculty of Forest Sciences and Forest Ecology, University of Göttingen, Büsgenweg 2, 37077 Göttingen, Germany 


\section{Introduction}

In Europe, cultivation of Northern red oak (Quercus rubra L.), a non-native tree species, has become increasingly popular since it expands the portfolio of forest enterprises and is thought to minimize management risks (Spellmann et al. 2011). A native of North America, Northern red oak is now found in large parts of Europe (Dreßel and Jäger 2002; Podhorski 1956; Rédei et al. 2010). Its main areas of cultivation include Belgium (Vansteenkiste et al. 2005), France (Magni Diaz 2004), and Germany (Dreßel and Jäger 2002). In Germany it is the most common non-native deciduous tree species, covering an area of 55,000 ha (Schmitz et al. 2014). Due to numerous advantages such as its rapid growth, drought, and storm resistance, Northern red oak is recommended for future cultivation (Klemmt et al. 2013; Kurjatko et al. 2006; NMELV 2004) and can be admixed, e.g., in pure pine stands (Kurjatko et al. 2006; NMELV 2004). Nevertheless, the response of Northern red oak to silvicultural interventions has not yet been adequately investigated outside of its natural distribution range (Burkardt et al. 2019). For example, questions such as how often Northern red oak stands are to be thinned and how intensively thinnings should be carried out are currently under debate (Nagel 2015). Generally speaking, thinnings are intended to reduce stand density and thus the competition intensity between trees (Kirk and Berrill 2016). Individual tree growth of future crop trees with this intervention should increase since they are released from competition (Burschel and Huss 2003). However, since branchiness of trees increases when competition is reduced by crown thinning, trade-offs exist between stem quality and diameter growth (Sonderman and Rast 1988). Therefore, optimised approaches are required to achieve both good stem quality and high yields.

To assess tree morphology objectively (Liang et al. 2011) and in a non-destructive way, terrestrial laser scanning (TSL) has been shown to be an appropriate method (Dorji et al. 2019; Schütt et al. 2004; Stängle et al. 2014). The resulting three-dimensional point clouds allow an exact calculation of various tree characteristics such as crown size or crown dimension (Juchheim et al. 2017; Seidel et al. 2011) which are closely related to tree productivity and thus to timber production (Roloff 1991; Seidel et al. 2019). Also, external stem characteristics such as lean or curved stems (Juchheim et al. 2017) and the number of branches and bark anomalies, which indicate stem quality (Burkardt et al. 2019; Höwler et al. 2017), can be computed. Finally, TLS-based approaches are also suitable to estimate competition intensity (Höwler et al. 2017; Metz et al. 2013). Terrestrial laser scanning cannot, however, account for the genetic controls on tree morphology and physiology.

The expression of tree characteristics is determined by genetic blueprint and inheritance, but the degree of genetic control differs between species (Zobel and Jett 1995). Gene sequencing technology has improved within the last decades by providing a wide selection of new gene markers (Paux et al. 2012). The most often utilized gene marker types are simple sequence repeats (SSRs) (Agarwal et al. 2008; Varshney et al. 2005) and can be classified into expressed sequence tag derived (EST-SSR) and nuclear simple sequence repeats (nSSR). EST-markers can provide insights into the link between phenotypic and genotypic variation (Gupta and Varshney 2000). The exact link between genes and their phenotypes remains somewhat unclear due to species' phenotypic plasticity, which complicates detection of underlying genes (Blue and Jensen 1988; Bruschi 2000). Because it is proportional to the amount of genetic variance at a locus, heterozygosity is an appropriate measure to examine the amount of genetic variation (Allendorf 1986). In population genetics, heterozygosity is usually studied when the genetic variation (i.e., following a genetic bottleneck or introduction of a species) is of interest. While Savolainen and Hedrick (1995) 
could not find any link between heterozygosity and fitness in Pinus sylvestris populations, Mitton et al. (1981) found a link between high levels of heterozygosity and high growth variability in aspen and ponderosa pine (Mitton et al. 1981). However, there are few examples whereby heterozygosity has been studied at the individual tree level (Yezerinac et al. 1992). Bergmann and Ruetz (1991) compared clones of Picea abies with randomly selected forest trees and found differences in the distribution of individual tree heterozygosity between the two groups.

To our knowledge there are no studies that have comparatively tested the influence of single tree heterozygosity and competition on tree characteristics of Northern red oak. In order to close this knowledge gap, the objective of our study was to explore which of the two properties influencing tree morphology is of more importance. More specifically, we hypothesized that:

1. Increasing competition results in reduced tree dimensions, more precisely in smaller crowns, fewer branches and fewer external stem characteristics of Quercus rubra L.

2. Competition effects on stem and crown characteristics are superimposed by genetic variation.

\section{Materials and methods}

\section{Study sites}

We studied a total of 100 study trees in ten Northern red oak stands located in five federal states within Germany (two each in Brandenburg, Thuringia, Lower Saxony, North RhineWestphalia and Baden-Württemberg). The sites were selected based on the following criteria: (1) stands should consist of at least $80 \%$ Northern red oak (basal area share), (2) stand age should be between 55 and 85 years (middle-aged), (3) stand size should be $\geq 1$ ha, (4) stands should show preferably large haplotype diversity (see Pettenkofer et al. 2019) and (5) sites should be classified as suitable for further cultivation of this species by local authorities.

\section{Silvicultural measurements}

A full tree inventory was conducted on all 10 study sites using the Field-Map instrument and software package (IFER-Monitoring and Mapping Solutions, Ltd., Czech Republic). We recorded each tree's coordinates, diameter at breast height and dominance [tree classes 1-5 according to Kraft (1884)]. For the analyses of tree morphology, ten dominant or (pre-) dominant study trees [tree classes 1-2 according to Kraft (1884)] were randomly selected within each of the ten study sites (for further information see Burkardt et al. 2019).

The sites covered a wide geographical and edaphic range, ranging from rather unfavourable sandy sites with low precipitation rates during the growing season of around $284 \mathrm{~mm}$ (Brandenburg) to richer sites with nutrient rich loess and high precipitation rates of around $400 \mathrm{~mm}$ (Baden-Württemberg) (Table 1).

To calculate the competition intensity to which each of the 10 target trees was exposed, we used the competition index according to Hegyi (1974). Both the diameter of all neighbouring trees (with $\mathrm{DBH} \geq 7 \mathrm{~cm}$ ) and their respective distance to the target tree (within an 


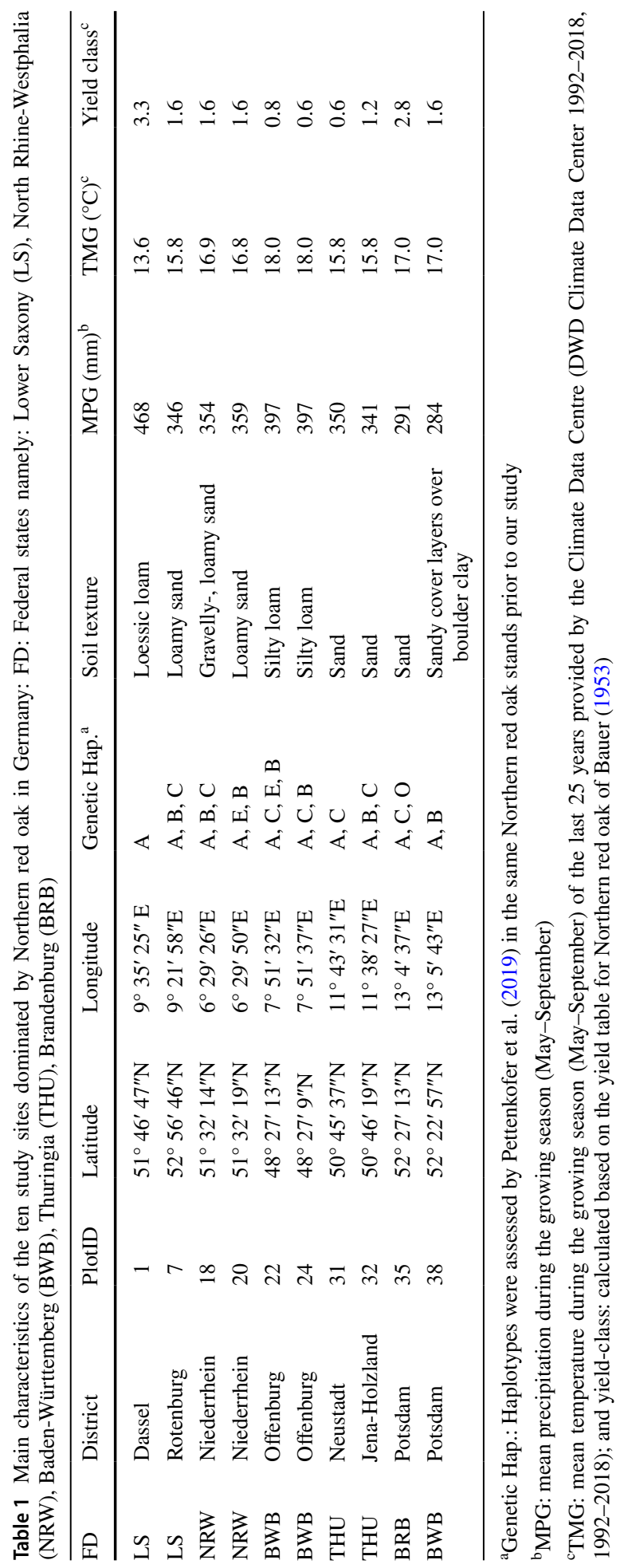


area of ca. $700 \mathrm{~m}^{2}(\mathrm{r}=15 \mathrm{~m})$ around each target tree) were included in the index calculation (Eq. 1).

$$
\text { Hegyi-index }=\sum_{i=1}^{n} \frac{D_{i}}{D_{j}} \times \frac{1}{D i s_{i j}},
$$

with target tree $j$, competitor tree $i$, diameter at breast height $(D$ in $\mathrm{cm})$ and the distance between target tree and the competitor tree (Dis in $\mathrm{m}$ ).

To assess stem and crown characteristics of the 10 target trees per site in a three-dimensional way, terrestrial laserscanning was applied using a Faro Focus 3D 120 laser scanner (Faro Technologies Inc., Lake Mary, Florida, USA). We applied the multiple scan approach (van der Zande et al. 2008), capturing each target tree from four or five directions (depending on stand density of the sourrounding neighbourhood). Between 15 and 25 artificial checkboard targets were mounted in the surroundings of the subject trees. Based on these targets, a spatial co-registration of the scans was performed using the software Faro Scene (Faro Technologies Inc, Lake Mary, FL, USA). The resulting three-dimensional point clouds had a registration error of less than $2 \mathrm{~cm}$ and included neighbouring trees and the surrounding vegetation up to a distance of $120 \mathrm{~m}$.

Each target tree was manually extracted from the overall point cloud using the CloudCompare Software [Cloud Compare 2.6, retrieved from (http://www.cloudcompare.org/)] and saved as an.xyz-file (Cartesian coordinates). Additionally, the trunk (from the root collar to the crown base height) was isolated from the individual tree point cloud and exported as an xyz-file to ensure a detailed analysis of the external stem characteristics (Burkardt et al. 2019).

Two different methods were used to analyze tree morphology. Quantitative Structural Models (QSM) were applied to describe branching structures and were calculated with the software Computree (Piboule et al. 2013), in accordance with Hackenberg et al. (2015). In these QSM models, each tree was characterized by a hierarchical collection of cylinders adapted to the local information of each point cloud (Raumonen et al. 2013). Based on the QSM models, crown characteristics were computed as follows: mean branch angle of first order branches, mean branch angle of second order branches, median branch angle zenith of first order branches, median branch angle zenith of second order branches, branch angle range of first order branches, branch angle range of second order branches, median branch length of first order branches, median branch angle zenith of second order branches (Figs. 1,2), mean- median- maximum-, and sum of branch length of first order branches.

Additionally, tree characteristics were derived directly from the point cloud of each tree. This included the following crown charateristics: crown base height $(\mathrm{CBH})$ (Metz et al. 2013), maximum crown area, mean crown radius (Seidel et al. 2015), crown length (TTH$\mathrm{CBH}$ ), crown asymmetry, crown surface area, and crown volume (Seidel et al. 2011). Stem measurements directly deduced from the point cloud were lean, sweep (Juchheim et al. 2017), mean stem non-circularity, and bark anomalies (Höwler et al. 2017).

Timber quality assessment of the stems was based on newly developed algorithms in the software Mathematica (Wolfram Research, Champaign, Illinois, USA). Following the German guidelines for the raw timber trade (RVR 2015) for stem quality grading, the threedimensional point clouds of the 100 stems of the target trees were virtually divided into $4 \mathrm{~m}$ long sections. These guidelines define tolerances for wood defects and categories of quality.

To homogenize the spatial resolution of the point clouds, a $1.75 \mathrm{~cm}$ point cloud grid (PCG) was processed for each stem section (Höwler et al. 2017; Seidel et al. 2011). PCGs 
Fig. 1 Graphical visualisation of the calculation of branch angle (zenith angle) of first order branches, based on the point cloud of the target trees derived from terrestrial laser scanning (TLS). $0_{1}{ }^{\circ}$ as main axis of a tree with $B_{1}$ as first order branch and $\alpha$ as the angle between the main axis and first order branches.

From the sum of the first-order branch angles per tree, mean value and median of the branch angles zenith were calculated. The branch angle range of first order branches was also computed. a Tree with small branch angles (zenith) of first order branches; $\mathbf{b}$ tree with medium large branch angles (zenith) of first order branches, and $\mathbf{c}$ tree with large branch angles (zenith) of first order branches

Fig. 2 Graphical visualisation of the mean branch angle zenith of second order branches based on the point cloud of the target trees derived from terrestrial laser scanning (TLS). From the sum of the second order branch angles per tree, mean value and median of the branch angles zenith were calculated. The branch angle range of second order branches was also computed, with $0_{2}^{\circ}\left(\mathrm{B}_{1}\right)$ as reference point, $\mathrm{B}_{2}$ as second order branch and $\beta$ as the angle between the two variables $0_{2}^{\circ}$ $\left(\mathrm{B}_{1}\right)$ and $\mathrm{B}_{2}$ second order
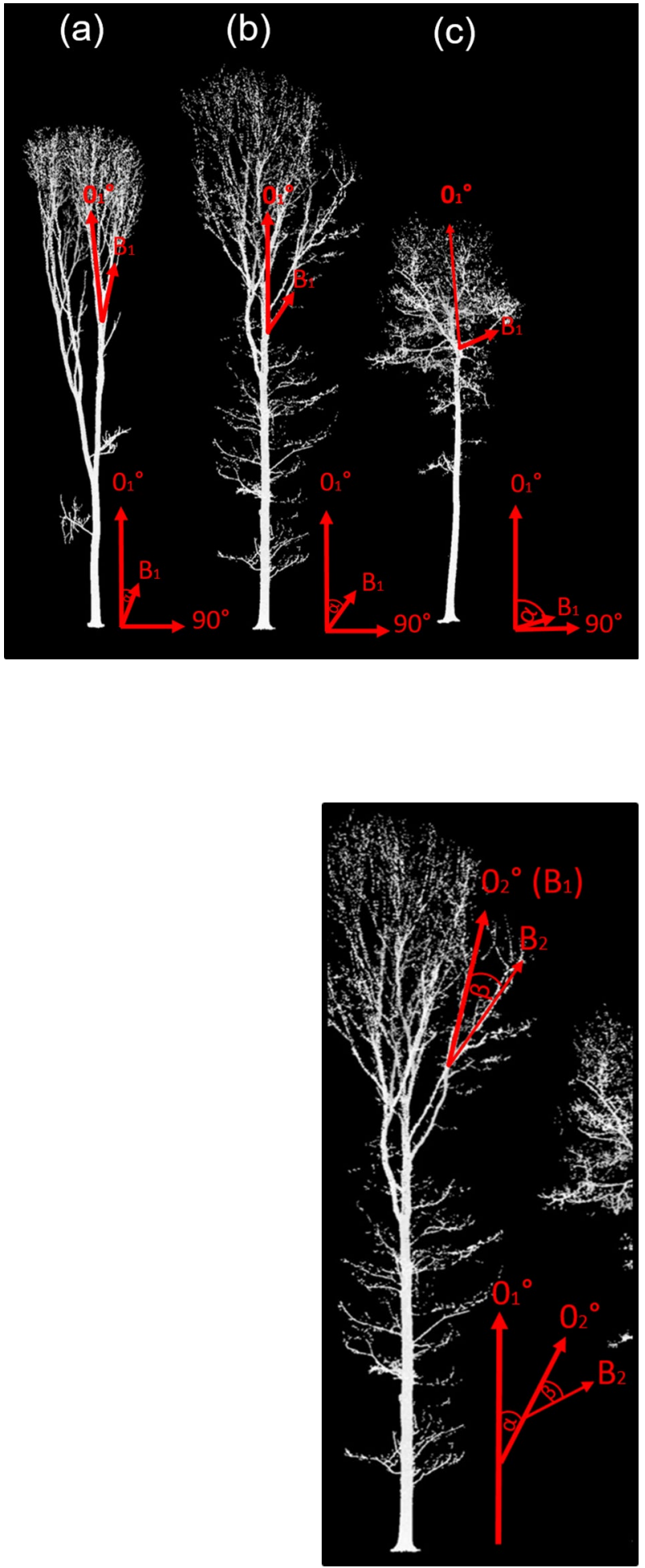
are used to eliminate density variations in the point cloud that can result from trees scanned from varying distances or with different numbers of scans. Examples are point density variations due to different scanner-to-tree distances, differences in scan-overlap due to different scan positions, or various understory vegetation heights or intensities (Burkardt et al. 2019; Höwler et al. 2017).

The following procedure was applied from the root collar to the level of the crown base to each $4 \mathrm{~m}$ stem section. Horizontal layers of $1.75 \mathrm{~cm}$ thickness were created from the previously homogenized stem point clouds (Höwler et al. 2017; Juchheim et al. 2017). These layers were then processed using "QR" decomsposition, which creates a circle to the points of each layer to factorize a matrix with "Q" as orthogonal and "R" as upper triangular matrix (Höwler et al. 2017; Seidel and Ammer 2014). The diameter and height of each generated circle and the centre point coordinates were saved. Horizontal differences between the lowest and highest circle positions of each trunk were defined as the measure for "total lean". "Total lean" was divided by the stem length, to ensure a length-independent value of lean. "Total sweep" was derived by using the ratio of the distances between the centers of all circles of each trunk section and the smallest distance between the centers of the lowest and highest circles within a trunk section of a tree. By dividing "total sweep" by the respective stem length, "sweep per meter" was obtained (Höwler et al. 2017).

The number of "bark anomalies" per metre and "stem non-circularity" were calculated to assess stem surface quality.

The "stem non-circularity" was calculated for each stem section using stem discs. The absolute differences between each point on the stem surface and the radius of the stem disc (derived from the circular fit for each disc) were determined for each stem disc (Höwler et al. 2017). For each layer, the mean value was computed from these absolute distances. The "stem-non-circularity" was then defined by computing the median of all height layers (Höwler et al. 2017).

The mean distance between each point on the disc surface and the respective disc centre was also determined. This measure was used to identify points that were further away from the centre of the parent disc than the mean distance plus standard deviation, or less than the mean distance minus standard deviation. These deviations of points from a fitted circle were defined as "bark anomalies" and were calculated for each stem individually. "Bark anomalies per meter" were calculated by dividing the value by the stem length.

\section{Genetic analyses}

For this study, we included twelve potentially adaptive (expressed sequence tag-derived simple sequence repeat $=$ EST SSR) and eight putative selective neutral nuclear microsatellite (nSSR) markers. The data obtained were part of a study conducted by Pettenkofer et al. (2020). EST-SSRs are located close to functional genes, in which variation is likely to be limited due to selection. They are more conserved than nSSR markers und thus show a higher transferability across species within genera. In contrast to this, nSSRs are highly polymorphic, being located in non-coding parts of the gene (Ellis and Burke 2007; Kalia et al. 2011). For this study, we calculated the individual tree-based heterozygosity group-wise for all markers $\left(\mathrm{H}_{\mathrm{o}} \mathrm{All}\right)$, for EST-derived markers $\left(\mathrm{H}_{\mathrm{o}} \mathrm{EST}\right)$ and for nSSRs ( $\mathrm{H}_{\mathrm{o}}$ Neutral). The included EST markers were FIR013, FIR024, FIR028, FIR031, FIR035, FIR104, GOT021, GOT040, VIT023, VIT107, PIE040, PIE125 (Durand et al. 2010). For more information on the selected markers, see Pettenkofer et al. (2020) and Supplementary material (Table 1). 
When conducting microsatellite analyses, fragment lengths of the examined gene loci are obtained. There is either one (homozygote) or two different alleles (heterozygote) present for each marker in one individual. The occurrence of heterozygosity is known to affect the fitness of an individual and thus the survival of a population under changing environmental conditions (Hansson and Westerberg 2002). In this study, heterozygosity was computed on the individual level separately for all markers, for EST-markers, and for putatively neutral markers. The value for heterozygosity $\mathrm{H}_{\mathrm{o}}$ reaches 1 when each examined marker of an individual has two different alleles. In contrast, $\mathrm{H}_{\mathrm{o}}=0$ when there is only one allele for each marker found. In this study, only samples with sufficient data ( $>75 \%$ of all markers per sample) were included. Since the individual based heterozygosity could not be calculated for all trees, the total dataset in this study, including the silvicultural measures, was adjusted to the 92 trees for which genetic data was available. The computed value for heterozygosity was then compared with phenotypic traits such as stem and crown characteristics.

\section{Statistical analyses}

All statistical analyses were implemented using the free statistics software ' $R$ ' (R Core Team 2018). Normal distribution of data was tested using the Shapiro-Wilk Test and variance homogeneity using Levene's test. Some dependent variables were log- or sqrt-transformed to obtain normally distributed residuals. Assuming a linear relation, we investigated the relationship between competition (Hegyi-Index), heterozygosity measured by EST-SSR markers " $\mathrm{H}_{\mathrm{O}} \mathrm{EST}$ ", heterozygosity measured by all markers " $\mathrm{H}_{\mathrm{O}} \mathrm{All",}$, and heterozygosity measured by nSSR markers " $\mathrm{H}_{\mathrm{O}}$ Neutral" as independent variables, and morphological tree characteristics as dependent variables. Plot-ID as was included in linear mixed effect models as random factor (lme fuction in "nlme" package). The update function in R was applied for model simplification by evaluating the parameter estimates and then deleting the least significant terms first by beginning with the top level interaction terms (Crawley 2007). We tested all stem characteristics of each stem section and all crown attributes for significance. In all examined relationships the random factor "idplot" enhanced the explained variance of the models.

Yield classes were derived for each study site using yield tables for Northern red oak (Bauer 1953). Better site conditions result in taller dominant trees at a given age (Burschel and Huss 2003). Linear models were used to assess whether yield classes alter the effect of heterozygosity or competition on Northern red oak tree characteristics (Table 2).

We also calculated Pearson correlation coefficients for relationships between crown (including branch) characteristics.

For all statistical analyses we used a significance level of $p<0.05$.

\section{Results}

\section{Effect of single tree heterozygosity on stem and crown characteristics}

Four crown characteristics were significantly related to heterozygosity measured by ESTSSR markers $\left(\mathrm{H}_{\mathrm{O}} \mathrm{EST}\right)$, which are located in expressed genes, and three crown attributes to heterozygosity measured group-wise for "All" markers $\left(\mathrm{H}_{\mathrm{O}} \mathrm{All}\right)$. Mean branch angle zenith $(p<0.01)$, branch angle range $(p<0.01)$ (Fig. 3), median branch angle zenith of 
Table 2 Results of the linear mixed effect models with the crown characteristics $\mathrm{BA}_{\text {mean }} 1 \mathrm{st}$ : mean branch angle of first order branches $\left({ }^{\circ}\right), \mathrm{BA}_{\text {median }} 1 \mathrm{st}$ : median branch angle of first order branches $\left(^{\circ}\right), \mathrm{BA}_{\text {range }} 1$ st: branch angle range of first order branches $\left({ }^{\circ}\right), \mathrm{NB} 1 \mathrm{st}$ : number of first order branches $(\mathrm{N}), \mathrm{BL}_{\text {sum }}$ : sum of branch length of first order branches $(\mathrm{N}), \mathrm{H}_{\mathrm{o}}$ EST: heterozygosity measured by EST-SSR markers, $\mathrm{H}_{\mathrm{o}}$ All: heterozygosity measured groupwise by all markers, $\mathrm{H}_{\mathrm{O}}$ Neutral: heterozygosity measured by nSSR markers as independent variables (Indep.), Random factor: Idplot, Intercept: the intercept of the model, independent: slope and $p$ value for each independent variable, Model: Akaike Information Criterion for the model, Adjusted R-Squared of the model (Adj.- $\mathrm{R}^{2}$ )

\begin{tabular}{|c|c|c|c|c|c|c|}
\hline \multirow[t]{2}{*}{ Crown characteristics } & \multirow[t]{2}{*}{ Indep. } & \multirow[t]{2}{*}{ Random f. } & \multirow[t]{2}{*}{ Intercept } & \multirow{2}{*}{$\begin{array}{l}\text { Indep. } \\
\mathrm{H}_{\mathrm{O}} \mathrm{Spec}\end{array}$} & \multicolumn{2}{|l|}{ Model } \\
\hline & & & & & $\overline{\mathrm{AIC}}$ & Adj. $-\mathrm{R}^{2}$ \\
\hline \multirow[t]{2}{*}{$\mathrm{BA}_{\text {mean }} 1 \mathrm{st}$} & $\mathrm{H}_{\mathrm{O}} \mathrm{EST}$ & Idplot & -65.33 & $\begin{array}{l}-22.53 \\
(p<0.01)\end{array}$ & 593.16 & 0.50 \\
\hline & $\mathrm{H}_{\mathrm{O}} \mathrm{All}$ & Idplot & 71.81 & $\begin{array}{l}-28.27 \\
(p=0.01)\end{array}$ & 595.17 & 0.47 \\
\hline \multirow[t]{2}{*}{$\mathrm{BA}_{\text {median }} 1 \mathrm{st}$} & $\mathrm{H}_{\mathrm{O}} \mathrm{EST}$ & Idplot & 62.87 & $\begin{array}{l}-26.42 \\
(p<0.01)\end{array}$ & 614.83 & 0.47 \\
\hline & $\mathrm{H}_{\mathrm{O}} \mathrm{All}$ & Idplot & 68.69 & $\begin{array}{l}-30.31 \\
(p=0.02)\end{array}$ & 618.12 & 0.44 \\
\hline \multirow[t]{2}{*}{$\mathrm{BA}_{\text {range }} 1 \mathrm{st}$} & $\mathrm{H}_{\mathrm{O}} \mathrm{EST}$ & Idplot & 179.82 & $\begin{array}{l}-26.78 \\
(p<0.001)\end{array}$ & 576.43 & 0.17 \\
\hline & $\mathrm{H}_{\mathrm{O}} \mathrm{All}$ & Idplot & 186.55 & $\begin{array}{l}-30.69 \\
(p<0.01)\end{array}$ & 580.69 & 0.11 \\
\hline NB1st & $\mathrm{H}_{\mathrm{O}} \mathrm{EST}$ & Idplot & 44.89 & $\begin{array}{l}-23.40 \\
(p=0.02)\end{array}$ & 641.25 & 0.29 \\
\hline $\mathrm{BL}_{\text {sum }}(\ln )$ & $\mathrm{H}_{\mathrm{O}}$ Neutral & Idplot & 3.47 & $\begin{array}{l}0.69 \\
(p=0.03)\end{array}$ & 75.32 & 0.18 \\
\hline
\end{tabular}

first order branches $(p<0.01)$ and the number of first order branches $(p=0.02)$ significantly decreased with increasing heterozygosity $\mathrm{H}_{\mathrm{O}}$ EST (Fig. 4). Mean branch angle zenith $(p<0.01)$, branch angle range $(p<0.01)$ (Fig. 3) and median branch angle zenith of first order branches also declined with increasing heterozygosity $\mathrm{H}_{\mathrm{O}} \mathrm{All}(p<0.01)$ (Table 2$)$.

Among all other tested branch and stem traits, only the sum of first order branches was related significantly to heterozygosity measured by nSSR markers $\left(\mathrm{H}_{\mathrm{O}} \mathrm{Neutral}\right)$, which are highly polymorphic and located in non-coding parts of the genome (Table 2, Supplementary Table 4).

\section{Effect of competition and site conditions on crown and stem characteristics}

Several crown characteristics were significantly related to competition intensity: crown volume, crown surface area, mean crown radius, maximum crown area, crown length, maximum branch length, mean branch length, and sum of branch length (Supplementary Table 4).

Other crown characteristics were not correlated with competition intensity: mean branch angle zenith of first order branches, mean branch angle zenith of second order branches, median branch angle zenith of first order branches, median branch angle zenith of second order branches, branch angle range of first order branches, branch angle range of second order branches, crown asymmetry, and number of first order branches (Supplementary Table 4). 

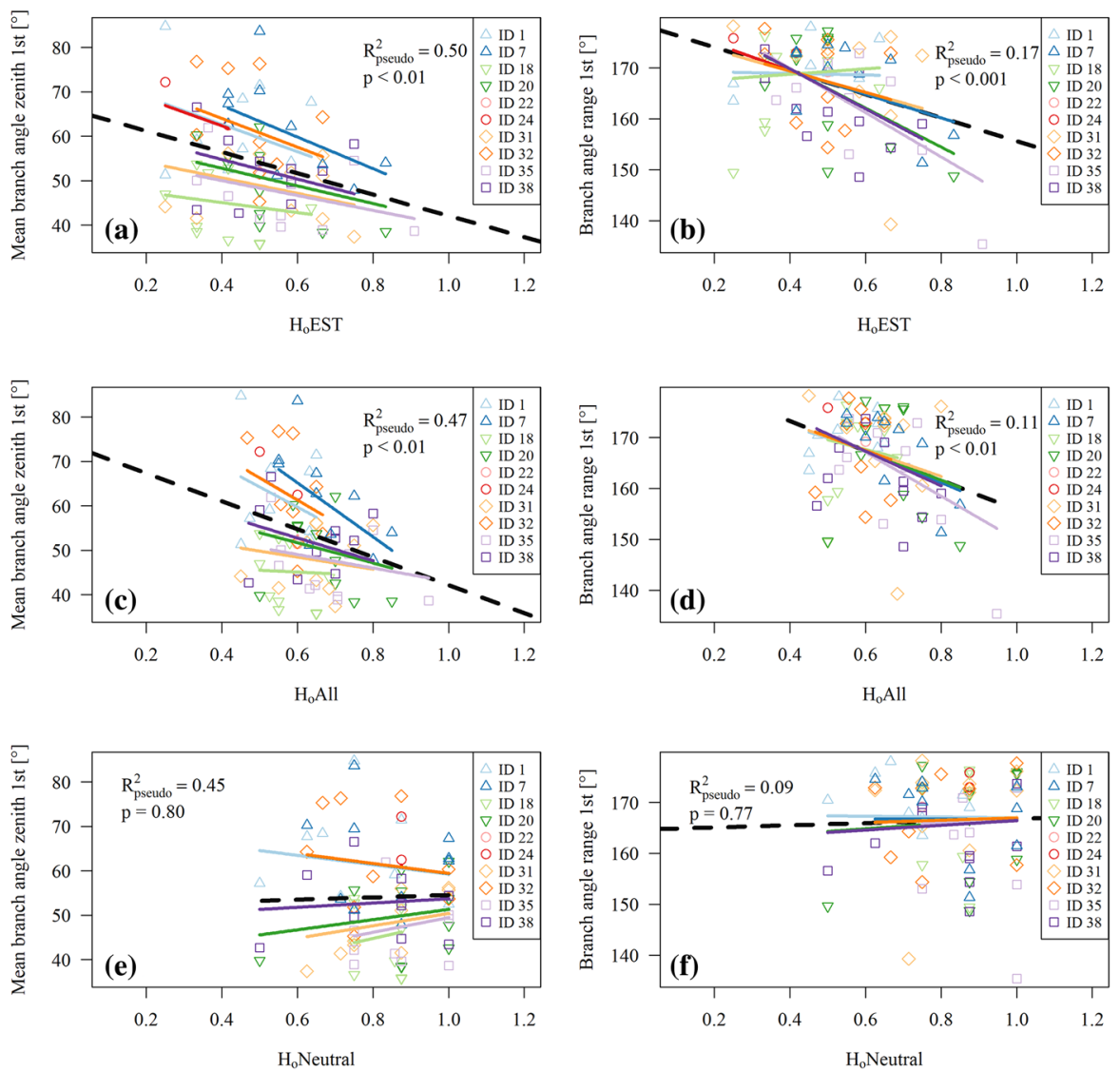

Fig. 3 Results of the linear mixed effect models: relationship between heterozygosity measured by ESTSSR markers " $\mathrm{H}_{\mathrm{O}} E S T$ " (a, b), heterozygosity measured by all markers " $\mathrm{H}_{\mathrm{O}} \mathrm{All}$ " (c, d) and heterozygosity measured by nSSR markers " $\mathrm{H}_{\mathrm{O}} \mathrm{Neutral}$ " $(\mathbf{e}, \mathbf{f})$ as independent variables, mean branch angle zenith 1 st order $(\mathbf{a}, \mathbf{c}, \mathbf{e})$ and branch angle range 1 st order $(\mathbf{b}, \mathbf{d}, \mathbf{f})$ as dependent variables on the ten study sites in Lower Saxony (ID 1: Dassel and ID 7: Rotenburg), North Rhine-Westphalia (ID 18 and ID 20, Lower Rhine region), Baden-Württemberg (ID 22 and ID 24; next to Offenburg), Thuringia (ID 31 and ID 32; next to Neustadt Orla) and Brandenburg (ID 35 and ID 38; next to Potsdam) as random factor

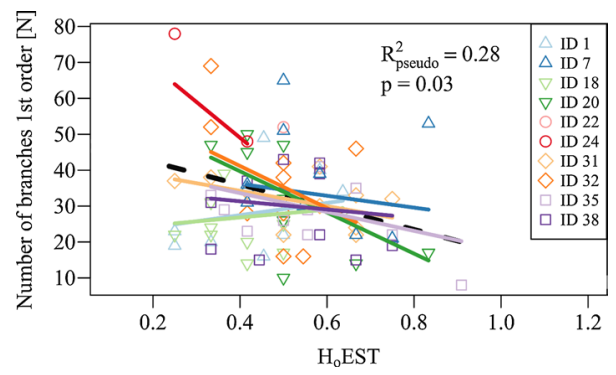

Fig. 4 Results of the linear mixed effect model: relationship between heterozygosity measured by EST-SSR markers " $\mathrm{H}_{\mathrm{O}} \mathrm{EST}$ " as independent variable and the number of first order branches as dependent variable on the ten study sites in Lower Saxony (ID 1: Dassel and ID 7: Rotenburg), North Rhine-Westphalia (ID 18 and ID 20, Lower Rhine region), Baden-Württemberg (ID 22 and ID 24; next to Offenburg), Thuringia (ID 31 and ID 32; next to Neustadt Orla) and Brandenburg (ID 35 and ID 38; next to Potsdam) as random factor 
Two of the four assessed stem characteristics were significantly related to competition intensity. The number of bark anomalies (0-4 m: $p<0.01 ; 4-8 \mathrm{~m}: p=0.03$ and $8-12 \mathrm{~m}$ : $p=0.05)$ and stem non-circularity of every stem section (0-4 m: $p<0.01,4-8 \mathrm{~m}: p<0.01$ and 8-12 m: $p<0.01)$ decreased with increasing competition. Lean and sweep of every stem section was not significantly related to competition (Supplementary Table 3).

In addition to competition, the site index significantly influenced three crown characteristics and one stem characteristic. With increasing site quality, crown surface area, mean crown radius, and mean branch length of first order branches increased and mean stem-non circularity decreased (Supplementary Table 5).

\section{Correlations between branch characteristics}

Mean branch angle and median branch angle of first order branches were significantly correlated with mean branch length, maximum branch length of first order branches and with the number of first order branches. Branch angles decreased (branch angles got steeper) with increasing mean- and maximum branch length of first order branches. Also, first order branch angles decreased with a decreasing number of first order branches (Table 3).

Branch angle range of first order branches and sum of branch length first order branches, as well as branch angle range of first order branches and the number of first order branches were positively correlated (Table 3 ).

No other crown characteristics were significantly correlated with the branch angle measurements (Supplementary Table 2).

\section{Discussion}

\section{Effect of single tree heterozygosity on branch angle traits}

The results of this study indicate that levels of heterozygosity play a role in shaping crown phenology of Quercus rubra since mean and median branch angle zenith as well as branch angle range of first order branches decreased with increasing heterozygosity "EST" and heterozygosity "All". This was a surprising finding, since if any relationship had been expected, the opposite would have been hypothesized; that increasing heterozygosity would be a driver of phenotypic plasticity.

Table 3 Results of the Pearson correlation with branch angle range ( $\mathrm{BA}_{\text {range }} 1 \mathrm{st}$ ), mean branch angle first order branches $\left(\mathrm{BA}_{\text {mean }} 1 \mathrm{st}\right)$, median branch angle first order branches $\left(\mathrm{BA}_{\text {median }} 1 \mathrm{st}\right)$ and mean branch length first oder branches ( $\left.\mathrm{BL}_{\text {mean }} 1 \mathrm{st}\right)$, maximum branch length first oder branches $\left(\mathrm{BL}_{\max } 1 \mathrm{st}\right)$ and of branch length first order branches $\left(\mathrm{BL}_{\mathrm{sum}} 1 \mathrm{st}\right)$ and number of first order branches (NB1st)

\begin{tabular}{llllllc}
\hline & $\begin{array}{l}\mathrm{BA}_{\text {range }} 1 \mathrm{st} \\
p \text { value }\end{array}$ & $\mathrm{BA}_{\text {mean }} 1 \mathrm{st}$ & $\mathrm{BA}_{\text {median }} 1 \mathrm{st}$ & $\begin{array}{l}\mathrm{BA}_{\text {range }} 1 \mathrm{st} \\
\rho \text { value }\end{array}$ & $\mathrm{BA}_{\text {mean }} 1 \mathrm{st}$ & $\mathrm{BA}_{\text {median }} 1 \mathrm{st}$ \\
\hline $\mathrm{BL}_{\text {mean }} 1 \mathrm{st}$ & 0.067 & 0.000 & 0.000 & -0.204 & -0.466 & -0.436 \\
$\mathrm{BL}_{\text {max }} 1 \mathrm{st}$ & 0.986 & 0.001 & 0.001 & 0.002 & -0.347 & -0.376 \\
$\mathrm{BL}_{\text {sum }} 1 \mathrm{st}$ & 0.000 & 0.584 & 0.678 & 0.424 & 0.062 & 0.047 \\
$\mathrm{NB} 1 \mathrm{st}$ & 0.000 & 0.000 & 0.000 & 0.480 & 0.496 & 0.475 \\
\hline
\end{tabular}

$p$ values $<0.05$ are shown in italics 
Phenotypic plasticity may be defined as the propensity of an individual to react to a changing environment by changing its phenotype (Schlichting 1986). High phenotypic plasticity would reflect a strong effect of the environment on the individual's phenotype (Schlichting 1986).

Our results contradict the majority of other studies, which did not find a correlation between phenotypic plasticity and heterozygosity (Scheiner 1993). Instead, it seems as if heterozygosity is positively correlated with developmental stability, a characteristic that refers to the ability of an individual to buffer its development against environmental influences. However, this does not necessarily mean alterations in morphology (Palmer and Strobeck 1986; Scheiner 1993).

In our study, higher levels of heterozygosity did not result in larger crowns, which seems at first glance to be an evolutionary disadvantage. However, steep first order branches and thus low branch zenith angles may simply reflect trees' ability to avoid competition by neighboring trees. Since crown structure affects the photosynthetic performance of a tree (Grote and Pretzsch 2002; Kuuluvainen 1991), smaller crowns are likely to lead to lower leaf area and thus to lower photosynthetic performance (Assmann 1970). However, no significant relationships were found between tree characteristics attributed to crown extension and branch angle measurements. Thus, it seems that the steeper first order branch angles do not result in smaller crowns and hence productivity. The ability to reach a certain crown size even with small zenith branch angles may be a competitive advantage. However, this remains highly speculative, perhaps due to our choice of a marker system that may not be able to reveal adaptation, and needs further investigation. Pettenkofer et al. (2020) conducted an outlier analysis to reveal markers under selection, but none could be found within German Northern red oak stands. Furthermore, none of the markers appear to be located close to genes that may play an important role in shaping Northern red oak's crown morphology. In addition to identification of potentially adaptive markers in Northern red oak through modern high-throughput-techniques like RADseq (restriction site associated DNA sequencing), potential candidate genes for shaping crown morphology should be analyzed in future studies. We cannot rule out, therefore, the possibility that our finding should perhaps be considered an artefact.

\section{Effect of competition intensity}

Reduction in the degree of competition to which the remaining trees are exposed is an important objective of (crown-) thinning interventions that aim to promote the growth of selected future crop trees (Puettmann et al. 2009). In fact, thinning intensity differed in our stands. Thus, our sample includes trees exposed to high but also to low competition from neighbouring trees. Our results clearly indicate that even if genetic properties play a role (this needs to be clarified), neighborhood competition is the main driver affecting most crown and stem characteristics.

Eight crown characteristics of Quercus rubra: crown volume, crown surface area, mean crown radius, maximum crown area, crown length, mean-, maximum- and sum of branch length of first order branches, decreased with increasing competition. These results are consistent with studies of other tree species showing that high inter- or intraspecific competition leads to a decrease in crown properties that are closely related to crown extension, crown size or crown dimensions (Bayer et al. 2013; Burkardt et al. 2019; Dieler and Pretzsch 2013; Dorji et al. 2019; Seidel et al. 2011; Thorpe et al. 2010). Since the degree of light acquisition by trees corresponds to their crown extension (Purves et al. 2007) 
reductions in crown size, for example crown length, due to competition, affects growth performance (Burkardt et al. 2019). Resource acquisition capacity is an important factor influencing reproduction, survival, and competitiveness of a tree (Tilman 1982).

Depending on the goal, wood production may focus not only on timber quantity but also on wood quality (Burschel and Huss 2003). The results of this study indicate that for Northern red oak, high competition intensities led to a decrease in external (i.e., undesirable) stem characteristics such as stem non-circularity and number of bark anomalies. The measure of the number of bark anomalies includes both branchiness and irregularities on the stem surface (stem injuries such as bark seams) (Richter 2010). Hence, we confirm findings of previous studies of species other than Northern red oak which found that high stand densities led to lower branchiness and to higher self-pruning (Ballard and Long 1988; Mäkinen 2002; Mäkinen and Hein 2006). Branch related wood defects are considered main drivers of decreasing stem quality for several tree species (Sonderman and Rast 1988). Thus, this study verifies that as is the case for many other tree species, Northern red oak needs, at least in stages of early stand development, higher competition intensities to produce high quality timber (Sonderman and Rast 1988). In the property 'bark anomalies', all forms of bark wounds are included that can serve as gateways for bacteria or fungi (i.e., white rot), considered as potential timber quality degraders (Schulz 1973). The proportion of bark wounds in the number of bark anomalies has to be examined, but in general bark anomalies have been proven to be an appropriate measure for predicting both external and inner stem quality (Burkardt et al. 2019; Höwler et al. 2019).

\section{Effect of environment/site conditions}

While site quality was shown to have an impact on crown characteristics and stem non-circularity of Northern red oak (Burkardt et al. 2019), none of the branch angle measurements were influenced by yield classes. Interestingly however, some branch angle attributes could be related to branch length. Branch development depends on many environmental and ecophysiological factors, for instance light conditions in the crown, as well as on water and nutrients allocated to the branch (Gross and Pham-Nguyen 1987; Lanner 1976). Smaller branch angles may indicate stronger competition between the branches within the crown, possibly leading to higher branch lengths and to a lower number of first order branches. In this study only (pre-) dominant Northern red oak trees were investigated. To inspect the relationship between branch angle measurements and environment, further studies with trees in different canopy layers are needed.

\section{Conclusions}

The objective of this study was to investigate whether heterozygosity or neighborhood competition shapes stem and crown characteristics of Northern red oak target trees. Branch angle values decreased with increasing heterozygosity. Beyond speculation, there is not yet a mechanistic explanation for this, but the results suggest that branch angles of Northern red oak trees may be, at least to some degree, genetically influenced. This result is unique and should be investigated in further studies with more specific gene markers and perhaps also with more heterogeneous Northern red oak stand qualities.

We conclude that even if a genetic influence cannot be excluded, competition is the main factor controlling various crown and stem characteristics. For silviculture with Northern 
red oak aiming at high quality timber, our results suggest that stands should be kept rather dense until self-pruning has been achieved up to a desired stem length. As Northern red oak is known for its phototropic growth and responsiveness, subsequent thinning operations could be moderate but frequent in order to promote crown size and thus tree productivity.

Acknowledgements The authors address thanks to Thomas Böckmann, the former head of the Lower Saxony Forestry Planning Department in Wolfenbüttel and Bernhard Mettendorf, ForstBW, for giving us access to forest sites. We gratefully acknowledge Nico Frischbier, ThüringenForst-AöR/Forstliches Forschungsund Kompetenzzentrum (FFK) and Bertram Leder, Forestry and Timber North Rhine Westphalia for providing us extensive stand specific information. We thank Alexandra Dolynska for technical assistance in the DNA lab. Special thanks goes to Andreas Parth for his technical assistance during fieldwork and for preparation and geo-referencing of the data. We also thank all foresters, for their assistance when selecting appropriate study stands. We are grateful to Kathleen Regan (USA) for linguistic corrections.

Author contributions Conceptualization, KB, TV, DS and CA; data curation, KB, formal analysis, KB, DS and TV, investigation, KB, methodology, KB, TV, DS, CA and OG; project administration, CA, TV and OG; supervision, TV, DS, and CA; writing - original draft, KB and TP [genetic analyses and parts of the effect of single tree heterozygosity on branch angle traits (discussion)], writing-review and editing, KB, TP, DS, TV, CA, OG, LL.

Funding Open Access funding enabled and organized by Projekt DEAL. The study was supported by the German Federal Ministry of Food and Agriculture (Funding Code 22023314). Part of this work, in particular the development of TLS-based quality measures was supported by funds of German government's Special Purpose Fund held at Landwirtschaftliche Rentenbank (FKZ: 844732) provided to Dominik Seidel.

\section{Compliance with ethical standards}

Conflict of interest The authors declare that they have no conflict of interest.

Open Access This article is licensed under a Creative Commons Attribution 4.0 International License, which permits use, sharing, adaptation, distribution and reproduction in any medium or format, as long as you give appropriate credit to the original author(s) and the source, provide a link to the Creative Commons licence, and indicate if changes were made. The images or other third party material in this article are included in the article's Creative Commons licence, unless indicated otherwise in a credit line to the material. If material is not included in the article's Creative Commons licence and your intended use is not permitted by statutory regulation or exceeds the permitted use, you will need to obtain permission directly from the copyright holder. To view a copy of this licence, visit http://creativecommons.org/licenses/by/4.0/.

\section{References}

Agarwal M, Shrivastava N, Padh H (2008) Advances in molecular marker techniques and their applications in plant sciences. Plant Cell Rep 27:617-631. https://doi.org/10.1007/s00299-008-0507-z

Allendorf FW (1986) Genetic drift and the loss of alleles versus heterozygosity. Zoo Biol 5:181-190

Assmann E (1970) The principles of forest yield study. Pergamon Press Ltd., Oxford

Ballard LA, Long JN (1988) Influence of stand density on log quality of lodgepole pine. Can J For Res 18:911-916. https://doi.org/10.1139/x88-138

Bauer F (1953) Die Roteiche. JD Sauerländer's Vertrag, Frankfurt am Main

Bayer D, Seifert S, Pretzsch H (2013) Structural crown properties of Norway spruce (Picea abies [L.] Karst.) and European beech (Fagus sylvatica [L.]) in mixed versus pure stands revealed by terrestrial laser scanning. Trees 27:1035-1047. https://doi.org/10.1007/s00468-013-0854-4

Bergmann F, Ruetz W (1991) Isozyme genetic variation and heterozygosity in random tree samples and selected orchard clones from the same Norway spruce populations. For Ecol Manag 46:39-47. https:// doi.org/10.1016/0378-1127(91)90243-O

Blue MP, Jensen RJ (1988) Positional and seasonal variation in Oak (Quercus; Fagaceae) leaf morphology. Am J Bot 75:939-947 
Bruschi P (2000) Morphological and Molecular Differentiation between Quercus petraea (Matt.) Liebl. and Quercus pubescens Willd. (Fagaceae) in Northern and Central Italy. Ann Bot 85:325-333. https://doi. org/10.1006/anbo.1999.1046

Burkardt K, Annighöfer P, Seidel D, Ammer C, Vor T (2019) Intraspecific competition affects crown and stem characteristics of non-native Quercus rubra L. stands in Germany. Forests 10:846. https://doi. org/10.3390/f10100846

Burschel P, Huss J (2003) Grundriss des Waldbaus: Ein Leitfaden für Studium und Praxis, 3. unchanged edn. Eugen Ulmer Verlag, Stuttgart

Crawley MJ (2007) The R book. Wiley, Chichester

Dieler J, Pretzsch H (2013) Morphological plasticity of European beech (Fagus sylvatica L.) in pure and mixed-species stands. For Ecol Manag 295:97-108. https://doi.org/10.1016/j.foreco.2012.12.049

Dorji Y, Annighöfer P, Ammer C, Seidel D (2019) Response of beech (Fagus sylvatica L.) trees to competition-new insights from using fractal analysis. Remote Sens 11:2656. https://doi.org/10.3390/rs112 22656

Dreßel R, Jäger EJ (2002) Beiträge zur Biologie der Gefäßpflanzen des herzynischen Raumes. 5. Quercus rubra L. (Roteiche): Lebensgeschichte und agriophytische Ausbreitung im Nationalpark Sächsische Schweiz. Hercynia N. F. 35:37-64

Durand J, Bodénès C, Chancerel E, Frigerio J-M, Vendramin G, Sebastiani F, Buonamici A, Gailing O, Koelewijn H-P, Villani F, Mattioni C, Cherubini M, Goicoechea PG, Herrán A, Ikaran Z, Cabané C, Ueno S, Alberto F, Dumoulin P-Y, Guichoux E, de Daruvar A, Kremer A, Plomion C (2010) A fast and cost-effective approach to develop and map EST-SSR markers: oak as a case study. BMC Genom 11:570. https://doi.org/10.1186/1471-2164-11-570

Ellis JR, Burke JM (2007) EST-SSRs as a resource for population genetic analyses. Heredity 99:125-132. https://doi.org/10.1038/sj.hdy.6801001

Gross K, Pham-Nguyen T (1987) Einfluss von langfristigem Wassermangelstress auf die Netto-Photosynthese und das Wachstum junger Fichten (Picea abies [L.] Karst) und Douglasien (Pseudotsuga menziesii [Mirb.] Franco. Forstwissenschaftliches Centralblatt 106:7-26

Grote R, Pretzsch H (2002) A model for individual tree development based on physiological processes. Plant Biol 4:167-180. https://doi.org/10.1055/s-2002-25743

Gupta PK, Varshney RK (2000) The development and use of microsatellite markers for genetic analysis and plant breeding with emphasis on bread wheat. Euphytica 113:163-185. https://doi.org/10.1023/A: 1003910819967

Hackenberg J, Spiecker H, Calders K, Disney M, Raumonen P (2015) Simpletree — an efficient open source tool to build tree models from TLS clouds. Forests 6:4245-4294. https://doi.org/10.3390/f6114245

Hansson B, Westerberg L (2002) On the correlation between heterozygosity and fitness in natural populations. Mol Ecol 11:2467-2474. https://doi.org/10.1046/j.1365-294X.2002.01644.x

Hegyi F (1974) A simulation model for managing jack-pine stands. In: Fries J (ed) Growth models for tree and stand simulation: International Union of Forestry Research Organizations Working Party S4. Skogshögskolan, Garpenberg, pp 74-90

Höwler K, Annighöfer P, Ammer C, Seidel D (2017) Competition improves quality-related external stem characteristics of Fagus sylvatica. Can J For Res 47:1603-1613. https://doi.org/10.1139/cjfr-2017-0262

Höwler K, Vor T, Seidel D, Annighöfer P, Ammer C (2019) Analyzing effects of intra- and interspecific competition on timber quality attributes of Fagus sylvatica L.- from quality assessments on standing trees to sawn boards. Eur J Forest Res 138:327-343. https://doi.org/10.1007/s10342-019-01173-7

Juchheim J, Annighöfer P, Ammer C, Calders K, Raumonen P, Seidel D (2017) How management intensity and neighborhood composition affect the structure of beech (Fagus sylvatica L.) trees. Trees 31:17231735. https://doi.org/10.1007/s00468-017-1581-z

Kalia RK, Rai MK, Kalia S, Singh R, Dhawan AK (2011) Microsatellite markers: an overview of the recent progress in plants. Euphytica 177:309-334. https://doi.org/10.1007/s10681-010-0286-9

Kirk C, Berrill J-P (2016) Second-log branching in multiaged Redwood and Douglas-Fir: influence of stand, site, and silviculture. Forests 7:147. https://doi.org/10.3390/f7070147

Klemmt H-J, Neubert M, Falk W (2013) Das Wachstum der Roteiche im Vergleich zu den einheimischen Eichen. LWF aktuell 97:28-31

Kraft G (1884) Beiträge zur Lehre von den Durchforstungen. Schlagstellungen und Lichtungshieben. Klindworth's, Hannover

Kurjatko S, Kúdela J, Lagaňa R (eds) (2006) Wood structure and properties' 06. Arbora Publishers, Zvolen

Kuuluvainen T (1991) Relationships between crown projected area and components of above-ground biomass in Norway spruce trees in even-aged stands: empirical results and their interpretation. For Ecol Manag 40:243-260. https://doi.org/10.1016/0378-1127(91)90043-U 
Lanner RM (1976) Patterns of shoot development in Pinus and their relationship to growth potential. See Ref 5:223-243

Liang X, Litkey P, Hyyppä J, Kaartinen H, Kukko A, Holopainen M (2011) Automatic plot-wise tree location mapping using single-scan terrestrial laser scanning. Photogramm J Finl 22:37-48

Magni Diaz CR (2004) Reconstitution de L'introduction de Quercus rubra L. En Europe et conséquences génétiques dans les populations allochtones. Dissertation, Ècole Nationale Du Génie Rural

Mäkinen H (2002) Effect of stand density on the branch development of silver birch (Betula pendula Roth) in central Finland. Trees 16:346-353. https://doi.org/10.1007/s00468-002-0162-x

Mäkinen H, Hein S (2006) Effect of wide spacing on increment and branch properties of young Norway spruce. Eur J For Res 125:239-248. https://doi.org/10.1007/s10342-006-0115-9

Metz J, Seidel D, Schall P, Scheffer D, Schulze E-D, Ammer C (2013) Crown modeling by terrestrial laser scanning as an approach to assess the effect of aboveground intra- and interspecific competition on tree growth. For Ecol Manag 310:275-288. https://doi.org/10.1016/j.foreco.2013.08.014

Mitton JB, Knowles P, Sturgeon KB, Linhart YB, Davis M (1981) Associations between heterozygosity and growth rate variables in three western forest trees, Berkeley

Nagel R (2015) Die Roteiche (Quercus rubra L.). In: Vor T, Spellmann H, Bolte A, Ammer C (eds) Potenziale und Risiken eingeführter Baumarten. Universitätsverlag Göttingen, Göttingen, pp 219-267

NMELV (ed) (2004) Langristige ökologische Waldentwicklung: Richtlinie zur Baumartenwahl: Schriftenreihe Waldentwicklung Niedersachsen, vol 54, Hannover

Palmer AR, Strobeck C (1986) Fluctuating asymmetry: measurement, analysis, patterns. Ann Rev Ecol Syst 17:391-421

Paux E, Sourdille P, Mackay I, Feuillet C (2012) Sequence-based marker development in wheat: advances and applications to breeding. Biotechnol Adv 30:1071-1088. https://doi.org/10.1016/j. biotechadv.2011.09.015

Pettenkofer T, Burkardt K, Ammer C, Vor T, Finkeldey R, Müller M, Krutovsky K, Vornam B, Leinemann L, Gailing O (2019) Genetic diversity and differentiation of introduced red oak (Quercus rubra) in Germany in comparison with reference native North American populations. Eur J For Res 10:803. https://doi.org/10.1007/s10342-019-01167-5

Pettenkofer T, Leinemann L, Gailing O (2020) Eine Übersicht zu Untersuchungen der Herkunft und genetischen Variation der Roteiche (Quercus rubra L.) in natürlichen und eingeführten Populationen*). Allg Forst- u J-Ztg 1/2:22-30. https://doi.org/10.23765/afjz0002036

Piboule A, Krebs M, Esclatine L, Hervé J-C (eds) (2013) Computree: a collaborative platform for use of terrestrial lidar in dendrometry

Podhorski I (1956) Der Anbau der Pappel und fremdländischer Holzarten in Jugoslawien. Allg Forstz 11:598-600

Puettmann KJ, Messier CC, Coates KD (2009) A critique of silviculture: managing for complexity. Island Press, Washington, DC

Purves DW, Lichstein JW, Pacala SW (2007) Crown plasticity and competition for canopy space: a new spatially implicit model parameterized for 250 North American tree species. PLoS ONE 2:e870. https://doi.org/10.1371/journal.pone.0000870

R Core Team (2018) R: a language and environment for statistical computing. R Foundation for Statistical Computing, Vienna, Austria

Raumonen P, Kaasalainen M, Åkerblom M, Kaasalainen S, Kaartinen H, Vastaranta M, Holopainen M, Disney M, Lewis P (2013) Fast automatic precision tree models from terrestrial laser scanner data. Remote Sens 5:491-520. https://doi.org/10.3390/rs5020491

Rédei K, Csiha I, Keserú Z, Rásó J, Győri J (2010) Management of red oak (Quercus rubra L.) stands in the Nyírség forest region (Eastern Hungary). Hung Agric Res 3:13-17

Richter C (2010) Holzmerkmale Beschreibung der Merkmale, Ursachen, Vermeidung, Auswirkungen auf die Verwendung des Holzes, technologische Anpassung, 3, updated and extended edn. DRWVerlag, Leinfelden-Echterdingen

Roloff A (1991) Tree structure and tree vitality. In: Longhurst JWS (ed) Acid deposition: origins, impacts and abatement strategies. Springer, Berlin, pp 193-213

Savolainen O, Hedrick P (1995) Heterozygosity and fitness: no association in scots pine. Genetics 140:755-766

Scheiner SM (1993) Genetics and evolution of phenotypic plasticity. Annu Rev Ecol Syst 24:35-68

Schlichting CD (1986) The evolution of phenotypic plasticity in plants. Ann Rev Ecol Syst 17:667-694

Schmitz F, Polley H, Hennig P, Kroiher F, Marks A, Riedel T, Schmidt U, Schwitzgebel F, Stauber T (2014) Der Wald in Deutschland. Ausgewählte Ergebnisse der dritten Bundeswaldinventur, Bonn. 
https://www.bundeswaldinventur.de/fileadmin/SITE_MASTER/content/Dokumente/Downloads/ BMEL_Wald_Broschuere.pdf. Accessed 21 May 2018

Schulz H (1973) Auswirkungen von Rückeschäden an jungen Buchen und Edellaubhölzern. Holzforschung 27:42-47. https://doi.org/10.1515/hfsg.1973.27.2.42

Schütt C, Aschoff T, Winterhalder D, Thies M, Kretschmer U, Spiecker H (2004) Approaches for recognition of wood quality of standing trees based on terrestrial laserscanner data. Int Arch Photogramm Remote Sens Spat Inf Sci 36:179-182

Seidel D, Ammer C (2014) Efficient measurements of basal area in short rotation forests based on terrestrial laser scanning under special consideration of shadowing. iForest 7:227-232. https://doi. org/10.3832/ifor1084-007

Seidel D, Leuschner C, Müller A, Krause B (2011) Crown plasticity in mixed forests-quantifying asymmetry as a measure of competition using terrestrial laser scanning. For Ecol Manag 261:2123-2132. https ://doi.org/10.1016/j.foreco.2011.03.008

Seidel D, Schall P, Gille M, Ammer C (2015) Relationship between tree growth and physical dimensions of Fagus sylvatica crowns assessed from terrestrial laser scanning. iForest 8:735-742. https://doi. org/10.3832/ifor1566-008

Seidel D, Annighöfer P, Stiers M, Zemp CD, Burkardt K, Ehbrecht M, Willim K, Kreft H, Hölscher D, Ammer C (2019) How a measure of tree structural complexity relates to architectural benefit-to-cost ratio, light availability, and growth of trees. Ecol Evol 9:7134-7142. https://doi.org/10.1002/ece3.5281

Sonderman DL, Rast ED (1988) Effect of thinning on mixed-oak stem quality NE-618

Spellmann H, Albert M, Sutmüller J, Overbeck M (2011) Waldbauliche Anpassungsstrategien für veränderte Klimaverhältnisse. AFZ-DerWald 11:19-23

Stängle SM, Brüchert F, Kretschmer U, Spiecker H, Sauter UH (2014) Clear wood content in standing trees predicted from branch scar measurements with terrestrial LiDAR and verified with X-ray computed tomography. Can J For Res 44:145-153. https://doi.org/10.1139/cjfr-2013-0170

Thorpe HC, Astrup R, Trowbridge A, Coates KD (2010) Competition and tree crowns: a neighborhood analysis of three boreal tree species. For Ecol Manag 259:1586-1596. https://doi.org/10.1016/j.forec o.2010.01.035

Tilman D (1982) Resource competition and community structure. Princeton University Press, Princeton

van der Zande D, Jonckheere I, Stuckens J, Verstraeten WW, Coppin P (2008) Sampling design of groundbased lidar measurements of forest canopy structure and its effect on shadowing. Can J Remote Sens 34:526-538. https://doi.org/10.5589/m08-070

Vansteenkiste D, Boever L de, van Acker J (2005) Alternative processing solutions for red oak (Quercus rubra) from converted forests in Flanders, Belgium. In: Proceedings of the COST action E44 conference on broad spectrum utilization of wood at BOKU Vienna, pp 13-26

Varshney RK, Graner A, Sorrells ME (2005) Genic microsatellite markers in plants: features and applications. Trends Biotechnol 23:48-55. https://doi.org/10.1016/j.tibtech.2004.11.005

Yezerinac SM, Lougheed SC, Handford P (1992) Morphological variability and enzyme heterozygosity, individual and population level correlations. Evolution 46:1959-1964

Zobel BJ, Jett JB (1995) Genetics of wood production. Springer Series in Wood Science. Springer, Berlin

Publisher's Note Springer Nature remains neutral with regard to jurisdictional claims in published maps and institutional affiliations. 